\author{
A. Selikhova ${ }^{1 *}$, A. Ospanova ${ }^{1}$, Y. Kanibolotskaya ${ }^{2}$ \\ ${ }^{1}$ Innovative University of Eurasia, Republic of Kazakhstan \\ ${ }^{2}$ Siberian University of Consumer Cooperation, Russia \\ *(e-mail: selihova_n@bk.ru)
}

\title{
General characteristics and taxonomic composition of epiphytic microflora of plants
}

\begin{abstract}
Main problem: Microbial-plant relationships, including epiphytic microflora, are the subject of attention of many scientists. Numerous works confirm the high interest of researchers and the relevance of studying this topic. Despite many years of research, some questions concerning the characteristics of the epiphytic microflora still remain open.

It is already a well-known fact that the epiphytic microflora is directly related to the physiological development of the plant, including yield. This is due to the close interaction of the plant with the microorganisms living on its surface throughout the entire growing season. It is also proved that epiphytic microflora has the ability to change characteristics under the influence of environmental factors (temperature, humidity, soil contamination, sunlight, etc.). In this regard, the study of this topic is one of the important areas of biological and agricultural sciences and is of high importance.

It should be noted that a significant role in the development of agriculture in the Republic of Kazakhstan and the Pavlodar region is played by representatives of vegetable crops, including tomatoes and potatoes belonging to the Solanaceae family, which indicates the high importance of the plants selected for the study. The combination of the above arguments determines the need to study the epiphytic microflora of plants and establish the regularities of its influence on the adaptive properties of the studied plants of the Solanaceae family, as well as on their productivity. In turn, the study of epiphytic microflora can also contribute to the search for new ways to increase the yield of plants and their resistance to various diseases.

Purpose: The article is devoted to the study of the properties and characteristics of the epiphytic microflora of the surface of various organs of plants of the Solanaceae family (on the example of tomato and potato). The variability of the composition and number of epiphytic microorganisms in seasonal dynamics is shown.

Methods: bacterioscopic method, fingerprint method, flushing method, Gram staining method.

Results and their significance: The characteristics and properties of representatives of epiphytic microorganisms of aboveground (leaf, fruit, flower) and underground (potato fruit) plant organs were studied. The role of the influence of environmental factors on the variability of epiphytic microflora is determined on the example of plants Lycopersicon esculentum Mill. (common tomato) and Solanum tuberosum L. (tuberous nightshade). The differences in the microflora of different plant organs in different periods of vegetation are shown.
\end{abstract}

Keywords: phyllosphere, carposphere, epiphytic microflora, phytopathogenic microorganisms.

\section{Introduction}

On the surface of all plant organs (mainly on the surface of the leaves), numerous microorganisms, which are called epiphytic, live and actively develop. In this mutually beneficial relationship, plants are the habitat and source of nutrients, and the epiphytic microflora, in turn, protects the plant from pathogenic microorganisms coming from outside, being, in fact, a specific barrier that provides the plant with immunity.

The study of this issue can contribute to the development of methods for improving the quality of agricultural crops, as well as their productivity. The purpose of the study of this topic is also to establish the laws of the influence of epiphytic microflora on the adaptive properties of plants.

The interaction of plants and microorganisms is actively studied by many scientists. Scottish scientists D. Graham and W. Hodgkiss were among the first to study epiphytic microflora. In 1967, they described the properties of 35 gram-negative bacteria that produce pigment isolated on the surface of plants [1].

The ability of epiphytic microflora to protect the plant from harmful effects was discovered by scientists D. Haas and S. Kiel. The fact that some strains of $P$. fluorescens can protect certain plant species from the effects of parasitic fungi, such as Fusarium or Pythium, as well as some phytophages of nematodes, they indicate in their study [2].

Later, when studying the genus Pseudomonas by the researcher S. Capdevila, it was possible to discover the ability of epiphytic microorganisms to compete with pathogenic bacteria [3].

In different periods of time, the properties and features of epiphytic microflora were studied by both foreign scientists and scientists from the CIS countries. To date, the study of epiphytic microflora is also of high interest, including for Kazakh researchers. 
Based on numerous studies by various scientists, it was found that approximately $64 \%$ of all microorganisms that collectively represent epiphytic microflora are bacteria (many forms: cocci, sticks, filamentous); $18 \%$ of the composition includes actinomycetes (thin branched mycelium), and another $18 \%$ are microscopic fungi and yeast (mycelium and spores). The data is shown in figure 1 .

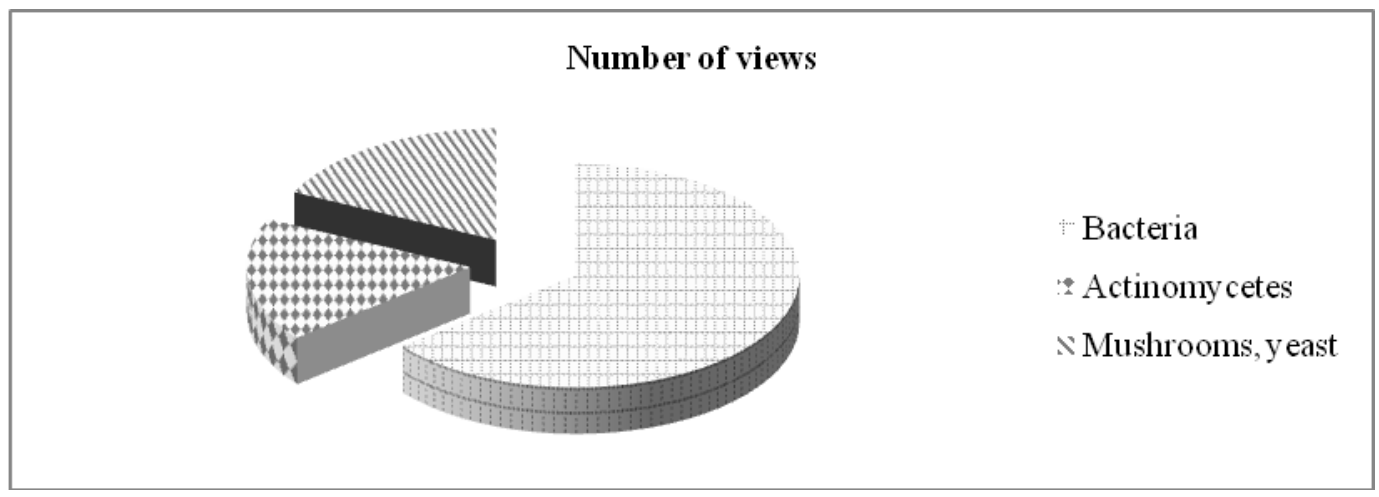

Figure 1 - List of microorganisms that are part of the epiphytic microflora

A number of studies suggest that the variability of environmental factors can affect the life and development of microorganisms. Such effects can include a direct change in the properties of microorganisms, acceleration or inhibition of their formation, and even death. Environmental factors that directly affect microorganisms are most often physical: humidity, temperature, sunlight, and others [4-6].

Materials and methods

On the example of tomato and potato the epiphytic microflora of plants of the Solanaceae family was studied. In the course of the study, the epiphytic microflora of the surface of the leaves, fruits and flowers of the tested plants was studied, as well as the dynamics, quantitative and specific composition of microorganisms of these plants was analyzed. Laboratory studies were conducted in 2020-2021 on the basis of the laboratory of the Department of Agriculture and Bioresources of the Innovative University of Eurasia, observations of plants were carried out in the period from May to September 2020 in the territory of the Pavlodar region.

The object of the study was microorganisms isolated from the upper surface of the phylloplan, the surface of flowers and fruits of the studied nightshade plants Lycopersicon esculentum Mill. (common tomato) and Solanum tuberosum L. (tuberous nightshade).

The study of the dynamics of seasonal fluctuations of epiphytic microflora was carried out by sampling by the method of prints and flushes from the upper surface of the phylloplan, the surface of flowers and fruits of plants.

The total bacterial contamination was calculated by the number of grown colonies and the amount of CFU in $1 \mathrm{ml}$ was determined by the formula:

$$
M=\frac{a+10^{m}}{V},
$$

$\mathrm{a}-$ the number of colonies grown;

$10^{\mathrm{n}}$ - breeding;

$\mathrm{V}$ - seed dose $(0.1 \mathrm{ml})$.

To study the morphological, cultural, and tinctorial properties of the isolated microorganisms, smears were made from the obtained colonies, and they were stained using the Gram method.

The identification of microorganisms was carried out using the Krasilnikov and Bergi bacterial determinants $[6,7]$.

Results

As a result of studying the epiphytic microflora on the surface of the leaves of the studied plants of the Solanaceae family (Lycopersicon esculentum Mill. Solanum tuberosum L.), we can observe the following picture: the number of microorganisms on the surface of the leaves at the beginning of the season (May-June) is less than on more "old" leaves (July-August). Since the beginning of autumn there is a change in weather conditions, including humidity and temperature, it should also be noted that during this period there is an increase in the contamination of the leaf surface with epiphytic microflora. At the same time, on the lower surface of the leaf, it is possible to observe a pattern of excess of the number of epiphytic microorganisms during the entire season (from May to September). This is due to the fact that for the lower surface of the leaf, sunlight is more difficult to access, respectively, the temperature in these parts of the plant is also reduced.

The epiphytic microflora of the leaf surface (phylloplan) is the most diverse in species composition compared to other parts of plants (flower, fruit). Thus, the microflora of Phylloplan is represented by the 
following types of microorganisms: Ps. fluorescence, Escherichia coli, Erwinia amylovora, Arthrobacter flavescens, Bacillus subtilis, B. cereus, B. megaterium, Lactobacillus plantarum.

More detailed data on the composition of the epiphytic microflora of Phylloplan are presented in table 1.

Table 1 - Composition of the microflora of phyllosphere plants of the family Solanaceae

\begin{tabular}{|c|c|c|c|c|}
\hline \multirow[t]{2}{*}{ Type of plant } & \multicolumn{2}{|l|}{ Bacteria } & \multicolumn{2}{|c|}{ Mushrooms } \\
\hline & Gram-positive & Gram-negative & yeast & mold fungi \\
\hline $\begin{array}{l}\text { Lycopersicon } \\
\text { esculentum } \\
\text { Mill. }\end{array}$ & $\begin{array}{l}\text { Bacillus subtilis, B. cereus, } \\
\text { B. megaterium; Paenibacillus } \\
\text { polymyxa, P. macerans, } \\
\text { Lactobacillus plantarum; } \\
\text { Kocuria rhizophila, } \\
\text { K. rosea, Arthrobacter } \\
\text { flavescens, } \\
\text { A. album, Rhodococcus flavum, } \\
\text { Sarcina maxima }\end{array}$ & $\begin{array}{l}\text { Pseudomonas } \\
\text { putida, } \\
\text { Ps. fluorescens, Ps. } \\
\text { Syringae, Ps. } \\
\text { liquefaciens, } \\
\text { Pantoae } \\
\text { agglomerans, } \\
\text { Escherichia coli }\end{array}$ & $\begin{array}{l}\text { Cryptococcus } \\
\text { albidus, } \\
\text { C. oleophila; } \\
\text { Rhodotorula } \\
\text { rubra, } \\
\text { Pullularia } \\
\text { pullulans. }\end{array}$ & $\begin{array}{l}\text { Aspergillus } \\
\text { niger, Mucor } \\
\text { mucedo, }\end{array}$ \\
\hline $\begin{array}{l}\text { Solanum } \\
\text { tuberosum L. }\end{array}$ & $\begin{array}{l}\text { Bacillus subtilis, B. megaterium, } \\
\text { A.album, Arthrobacter flavescens, } \\
\text { Lactobacillus plantarum, } \\
\text { Kocuria } \\
\text { rhizophila, Staphylococcus } \\
\text { saprophiticus, Bac. } \\
\text { licheniformis. }\end{array}$ & $\begin{array}{l}\text { Pseudomonas } \\
\text { chlororaphis, Ps. } \\
\text { Aeruginosa, Ps. } \\
\text { Desmolytica, } \\
\text { Escherichia coli, } \\
\text { Erwinia herbicola, } \\
\text { Pantoae } \\
\text { agglomerans }\end{array}$ & $\begin{array}{l}\text { Cryptococcus } \\
\text { albidus, } \\
\text { Candida } \\
\text { tolerans, } \\
\text { C. oleophila; } \\
\text { Aerobasidium } \\
\text { pullulans, } \\
\text { Rhodotorula } \\
\text { glutinis }\end{array}$ & $\begin{array}{l}\text { Aspergillus } \\
\text { niger, Mucor } \\
\text { racemosus }\end{array}$ \\
\hline
\end{tabular}

The properties inherent in the epiphytic microflora of the leaf surface of the studied plants have a high numerical and taxonomic variability, which directly depends on the localization on different parts of the plant (leaves, fruits or flowers), seasonal changes in the plants themselves, the growing season and weather conditions.

Thus, the microbial epiphytic complex formed on the surface of the phylloplan has the property of changing depending on the stage of plant development and differs in the specific and quantitative ratio of individual groups and species of microorganisms in different periods of vegetation. For example, the "young" leaves of plants are populated, for the most part, by bacteria, while the aging leaves increase the content of yeast and fungi.

The epiphytic microflora of Phylloplan is quite diverse in its qualitative composition and its typical representatives are: Ps. fluorescens, Ps. aeruginosa, Bac. megaterium, Bac.subtilis, Bac. vulgatus, Paenibacillus polymyxa, Lactobacillus plantarum, Staphylococcus saprophiticus, E. Coli, Candida tolerans, Erwinia herbicola.

Phytopathogenic bacteria were also isolated from the phylloplan surface of the studied plants: Pseudomonas syringae, Bac. vulgatus, Erwinia amylovora, Bac. mesentericus. As we know, epiphytic microflora is not pathogenic, but it can change under certain conditions. Sources of infection can be soil, ground and rain water, insects and artificial damage to plants.

The study of the composition of the microflora of two plants of the same family showed that the representatives of microorganisms on different plants are almost the same.

Data on the number of microorganisms on the surface of tomato and potato leaves in seasonal dynamics are presented in table 2 and figure 2 .

Table 2 - The number of microorganisms on the phyllosphere surface in seasonal dynamics

\begin{tabular}{|c|c|c|c|c|c|c|c|c|c|c|}
\hline \multirow{3}{*}{ Plant } & \multicolumn{10}{|c|}{ Number of microbial colonies per $1 \mathrm{~cm}^{2}$} \\
\hline & \multicolumn{2}{|c|}{ May } & \multicolumn{2}{|c|}{ June } & \multicolumn{2}{|c|}{ July } & \multicolumn{2}{|c|}{ August } & \multicolumn{2}{|c|}{ September } \\
\hline & 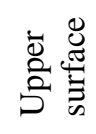 & 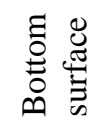 & 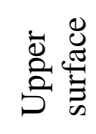 & 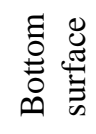 & 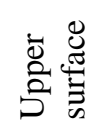 & 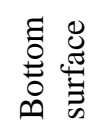 & 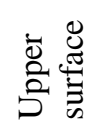 & 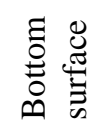 & 㐫 & 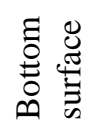 \\
\hline $\begin{array}{l}\text { Lycopersicon } \\
\text { esculentum Mill. }\end{array}$ & 4,5 & 5,13 & 5,2 & 5,84 & 5,14 & 5,78 & 5,61 & 6,17 & 9,55 & 10,35 \\
\hline $\begin{array}{l}\text { Solanum } \\
\text { tuberosum L. }\end{array}$ & 5,14 & 6,0 & 5,09 & 5,93 & 5,02 & 5,74 & 5,96 & 6,71 & 9,75 & 10,74 \\
\hline
\end{tabular}




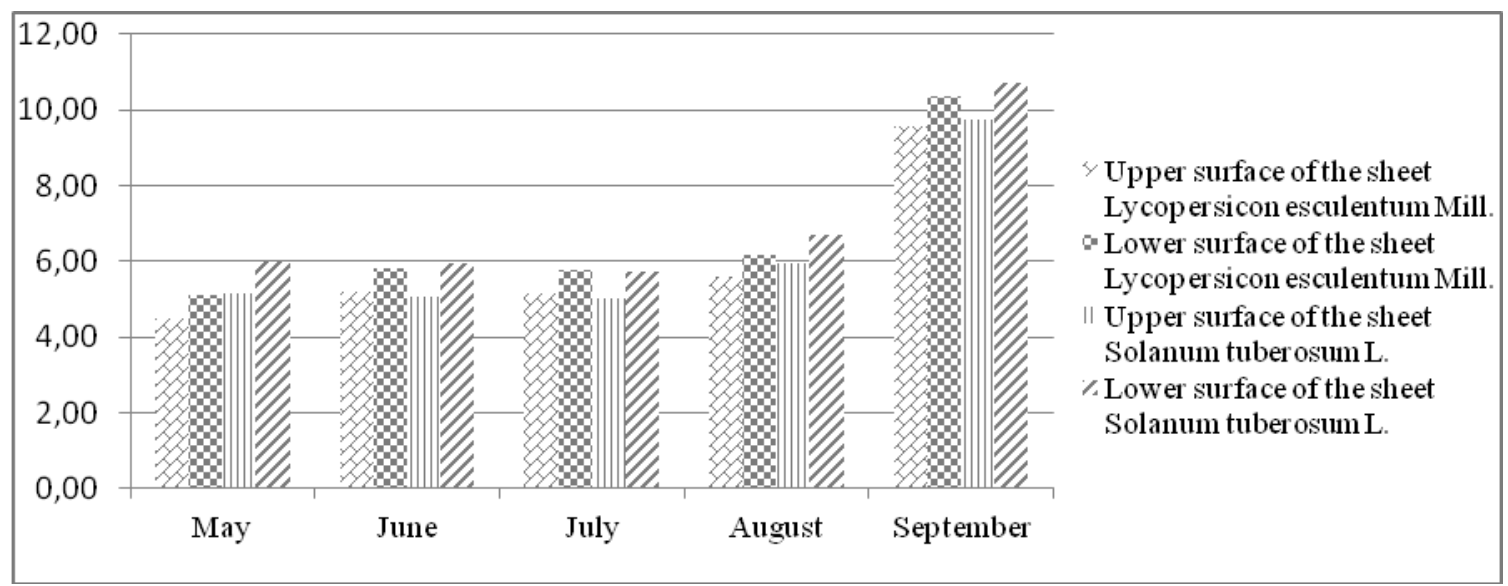

Figure 2 - The number of microorganisms on the phyllosphere surface in seasonal dynamics

During the observation period (from May to September 2020), we can observe the following fluctuations in temperature and humidity (Table 3).

Table 3 - Temperature and humidity fluctuations during the study period

\begin{tabular}{|l|c|c|c|c|c|}
\hline \multicolumn{1}{|c|}{ Month } & May & June & July & August & September \\
\hline $\begin{array}{l}\text { Average } \\
\text { temperature }\end{array}$ & $+13,4 \mathrm{C}^{\mathrm{O}}$ & $+19,8 \mathrm{C}^{\mathrm{O}}$ & $+20,9 \mathrm{C}^{\mathrm{O}}$ & $+19,2 \mathrm{C}^{\mathrm{o}}$ & $+12,2 \mathrm{C}^{\mathrm{c}}$ \\
\hline $\begin{array}{l}\text { Average } \\
\text { humidity }\end{array}$ & $47 \%$ & $52 \%$ & $61 \%$ & $59 \%$ & $64 \%$ \\
\hline
\end{tabular}

As we have already pointed out above, the number and species composition of epiphytic microflora varies depending on many factors, including the temperature and humidity of the environment. Since the humidity can be considered sufficient, and the temperature is quite favorable (Table 3), in the summer we can observe active microflora of the genera Pseudomonas and Bacillus on the upper surface of the phylloplan of plants, with the predominance of species of the genus Pseudomonas. At the same time, in the autumn period, spore-forming bacteria of the genus Bacillus predominate, the number of which increases by an average of $40.1 \%$ compared to the previous months, and the number of Pseudomonas species decreases by $36.9 \%$.

The data is presented in table 4 and figure 3.

Table 4 - Number of Pseudomonas and Bacillus colonies isolated from the phylloplan surface of the studied plants in the summer-autumn period

\begin{tabular}{|l|c|c|c|c|}
\hline \multirow{2}{*}{ Name of the plant } & \multicolumn{2}{|c|}{ Number of Bacillus colonies } & \multicolumn{2}{c|}{ Number of Pseudomonas colonies } \\
\cline { 2 - 5 } & summer & autumn & summer & autumn \\
\hline $\begin{array}{l}\text { Lycopersicon } \\
\text { esculentum Mill. }\end{array}$ & 89,72 & 136,12 & 103,52 & 76,30 \\
\hline $\begin{array}{l}\text { Solanum tuberosum } \\
\text { L. }\end{array}$ & 98,14 & 153,22 & 136,28 & 90,42 \\
\hline
\end{tabular}

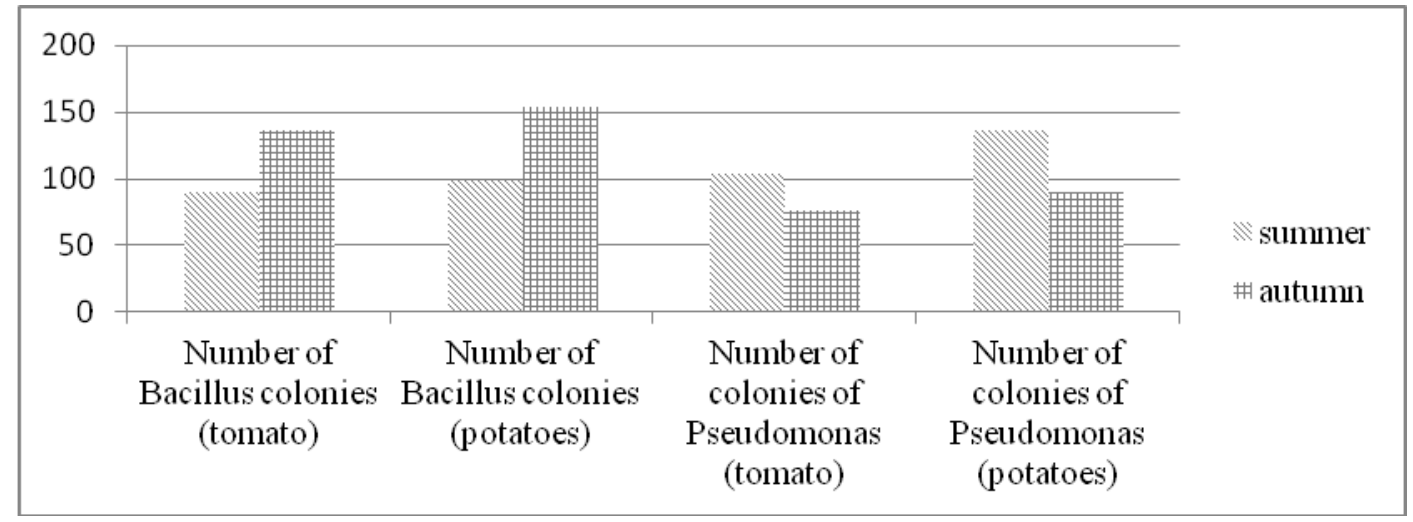

Figure 3 - Number of Pseudomonas and Bacillus colonies isolated from the phylloplan surface of the studied plants in the summer-autumn period 
Let's move on to the next part of the plants - the fruit. The surface of the fruits of plants is called the carposphere. The number of microorganisms in the carposphere was also studied by the fingerprint method. The number of colonies isolated after the experiment was recalculated by the total area of the fetus. Thus, the content of microorganisms per $1 \mathrm{~cm} 2$ was calculated. Quantitative indicators of bacteria isolated from the fruit surface of the studied plants of the Solanaceae family are presented in Table 5 and Figure 4.

Table 5 - Number of microorganisms in the carposphere of tomato and potato plants (in summer)

\begin{tabular}{|l|c|c|c|}
\hline \multirow{2}{*}{ Plant } & \multicolumn{3}{|c|}{ Number of microorganisms per 1 $\mathrm{cm}^{2}$} \\
\cline { 2 - 4 } & June & July & August \\
\hline $\begin{array}{l}\text { Lycopersicon } \\
\text { esculentum Mill. }\end{array}$ & 4,7 & 5,24 & 12,4 \\
\hline Solanum tuberosum L. & 3,3 & 5,59 & 11,8 \\
\hline
\end{tabular}

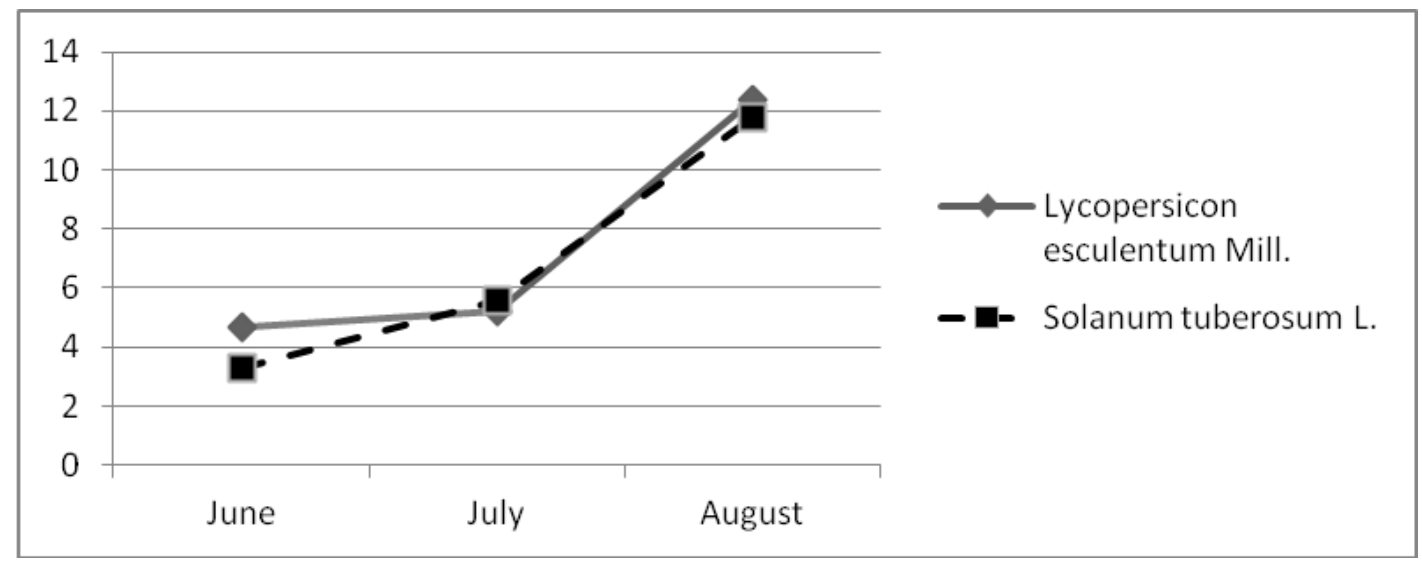

Figure 4 - Number of microorganisms in the carposphere of tomato and potato plants (in summer)

The number of epiphytic microorganisms on the surface of the fruit, as well as on the leaves, increases from the beginning to the end of the growing season of the plant as they mature. According to the species composition, the epiphytic microflora on fruits is the most diverse in comparison with the leaves and flowers and is represented by the following types of bacteria and yeast: Pseudomonas chlororaphis, Ps. liquidaciens, Ps. aeruginosa, Ps. fluorescens, Ps. radiobacter, Ps. putida, Ps. desmolytica, Escherichia coli, Erwinia amylovora, Arthrobacter album, Arthrobacter flavescens, Kocuria rosea, K. Rhizophila, Rhodococcus flavum, Sarcina maxima, Lactobacillus plantarum, Bacillus subtilis, Bac. Megaterium, Candida albicans. Micromycetes of the carposphere are represented by the following composition: Aspergillus flavus, Aspergillus niger, Mucor racemosus.

Speaking about the epiphytic microflora of the surface of the flowers of the studied plants, it should be noted that the number of epiphytic microorganisms during the flowering period of tomatoes and potatoes is subject to slight fluctuations.

Clearly, the data on the number of microorganisms per $1 \mathrm{~cm} 2$ of the flower are shown in Table 6.

Table 6 - The number of microorganisms on the surface of the flowers of the studied plants of the Solanaceae family

\begin{tabular}{|l|c|c|}
\hline \multicolumn{1}{|c|}{ Plant } & The beginning of flowering & End of flowering \\
\hline Lycopersicon esculentum Mill. & 2,1 & 4,8 \\
\hline Solanum tuberosum L. & 1,7 & 3,7 \\
\hline
\end{tabular}

As we can see from the table, the number of microorganisms on the surface of the flower increases from the beginning of flowering to the end (the pattern is the same as in fruits and leaves).

The microflora of the flower only partially depends on the microflora of the plant itself, since this organ is sterile when the flower is laid. To a greater extent, the composition of the microflora depends on the microflora introduced from other plants by pollinating insects. The contamination of flowers by microorganisms changes significantly as the flowers are pollinated by insects. At the beginning of flowering, the flower is only populated by typical epiphytic microorganisms, and by the end of flowering, the microflora contains species that are not typical for epiphytic microflora (Bacillus thurigiensis, Hafnia alvei, Streptococcus apis, Enterococcus faecalis). At the same time, the microflora of flowers is characterized by the greatest variety of yeasts: Bullera sp., Candida albicans, Cryptococcus albidus, Pichia farionosa, Pullularia pullulans, Metchnikowia puleherrima, Rhodotorula mucilaginosa, Rhodotorula glutinis, Sporobolomyces roseus, Zygosaccharomyces sp.

Thus, the diversity of the microflora of the plant surface during the flowering period is associated with the activity of pollinating insects that introduce atypical microflora. 
The study of the composition of the epiphytic microflora of plants of the Solanaceae family showed that the microflora of the surface of the flowers, phylloplan and carposphere is different in composition and saturation. The largest number of microorganisms is characteristic of Phylloplan, and the greatest diversity is characteristic of the carposphere. The variability and dynamics of epiphytic microflora can be traced throughout the observation period. The greatest number of microorganisms on the surface of plants was found in September.

\section{Discussion}

Epiphytic microflora is a complex of microorganisms that live and actively develop on the surface of plants. As a rule, it includes representatives of bacteria (most species), actinomycetes, fungi and yeast. The mutually beneficial interaction between the epiphytic microflora and plants allows the latter to protect themselves from the effects of pathogenic bacteria, thus, the epiphytic microflora serves as a protective barrier for the plant. In turn, for epiphytic microorganisms, such a habitat is an advantage, since it contains a huge amount of nutrients.

The quantitative and qualitative composition of the epiphytic microflora is directly dependent on factors such as humidity, temperature, sunlight, as well as the age of the plant.

In the seasonal dynamics of various parts of the plant (leaves, fruits, flowers), an increase in the number of epiphytic microflora is observed from the beginning to the end of the growing season. The most diverse epiphytic microflora is found on the fruits of plants (carposphere), the most numerous - on the leaves (phyllosphere).

\section{Conclusion}

A study of two species of plants in the Solanaceae family (Lycopersicon esculentum Mill. and Solanum tuberosum L.) allows us to draw the following conclusions:

1. The species composition of the epiphytic microflora is diverse and differs on individual parts of the plant (leaf, fruit, flower). At the same time, the microflora of two plants of the same family practically does not differ in species composition.

2. The age of the plant, fluctuations in temperature and humidity, and the amount of sunlight affect the variability in the amount and composition of epiphytic microflora. It should also be noted that in the summer there is a high contamination of the phyllosphere with microorganisms of the genera Bacillus and Pseudomonas.

3. Species composition of the phyllosphere of epiphytic microorganisms of the plant Lycopersicon esculentum Mill. is represented by 24 species, including 12 gram-positive, 6 gram-negative, 4 types of yeast and 2 types of mold fungi. Solanum tuberosum L. is seeded with the following composition of microflora: 8 Grampositive bacteria, 6 gram-negative, 5 types of yeast and 2 types of mold fungi - a total of 21 types of microorganisms.

4. Most representatives of the epiphytic microflora are non-pathogenic, but there are also pathogenic species among them.

The study of the ecological role of plant microflora is of great interest and has valuable practical value.

\section{THE LIST OF SOURCES}

1 Graham, D., Hodgkiss W. Identity of gram negative, yellow pigmented, fermentative bacteria isolated from plants and animals: scientific article - J. Appl. Bacteriol, 1967. - pp. 175-189.

2 Haas,D., Keel, C. Regulation of Antibiotic Production in Root-Colonizing Pseudomonas spp. and Relevance for Biological Control of Plant Disease: scientific article - Annual Review of Phytopathology, 2003. - pp. 6-10.

3 Capdevila, S., Martínez-Granero, F., Sánchez-Contreras, M., Rivilla, R., Martín, M. Analysis of Pseudomonas fluorescens F113 genes implicated in flagellar filament synthesis and their role in competitive root colonization: scientific article - Microbiology (Reading), 2004. - pp. 5-14.

4 Широков О.Г. Взаимоотношения между микроорганизмами как фактор формирования эпифитной микрофлоры: учебник - Москва: Изд-во МГУ, 1963. - С. 73-77.

5 Самцевич С.А. О влиянии условий внешней среды на взаимоотношения между микроорганизмами почвы и высшими растениями: автореф. дис. на соискание уч. степени - Ленинград: АН СССР, 1961. С. 29-31.

6 Ждан-Пушкина С.М. Основы роста культур микроорганизмов: учебное пос. - Ленинград: Изд-во ЛГУ, 1983.- $108 \mathrm{c}$.

\section{REFERENCES}

1 Graham, D., Hodgkiss, W. Identity of gram negative, yellow pigmented, fermentative bacteria isolated from plants and animals: scientific article - J. Appl. Bacteriol, 1967. - pp. 175-189. [in English].

2 Haas, D., Keel, C. Regulation of Antibiotic Production in Root-Colonizing Pseudomonas spp. and Relevance for Biological Control of Plant Disease: scientific article - Annual Review of Phytopathology, 2003. - pp. 6-10. [in English].

3 Capdevila, S., Martínez-Granero, F., Sánchez-Contreras, M., Rivilla, R., Martín, M. Analysis of Pseudomonas fluorescens F113 genes implicated in flagellar filament synthesis and their role in competitive root colonization: scientific article - Microbiology (Reading), 2004. - pp. 5-14. [in English]. 
4 Shyrokov, O.G. (1963). Vzaimootnosheniya mezhdu organizmami kak factor formirovaniya epifitnoy microflory [Relationships between microorganisms as a factor in the formation of epiphytic microflora]. Moskva: Izd. MGU [in Russian].

5 Samtsevich, S.A. (1961). O vliyanii usloviy vneshney sredy na vzaimootnosheniya mezhdu mikroorganizmami pochvy I vysshymi rasteniyami [On the influence of environmental conditions on the relationship between soil microorganisms and higher plants]. Extended abstract of candidate's thesis. Leningrad [in Russian].

6 Zhdan-Pushkina, S.M. (1983). Osnovy rosta kul'tur microorganizmov [Fundamentals of microbial culture growth]. Leningrad: Izd. LGU [in Russian].

\author{
А.А. Селихова ${ }^{1}$, А.К. Оспанова ${ }^{1}$, Ю.М. Каниболоцкая ${ }^{2}$ \\ ${ }^{1}$ Инновациялық Еуразия университеті, Қазақстан Республикасы \\ ${ }^{2}$ Сібір тұтынушылар кооперациясы университеті, Ресей
}

\title{
Өсімдіктердің эпифиттік микрофлорасының жалпы сипаттамасы және таксономиялық құрамы
}

Өсімдік-микробтардың өзара әрекеттесуін зерттеу - бүгінгі күні биологиялық және ауылшаруашылық ғылымдарының өзекті мәселелерінің бірі. Бұл мәселені зерттеген көптеген ғалымдар эпифитті микрофлораның өсімдіктердің өсуіне және дамуына әсер ететінін, сонымен қатар кірістілікке айтарлықтай әсер ететінін анықтады, өйткені ол бүкіл вегетация кезеңінде өсімдікпен тығыз байланыста болады. Сонымен қатар, эпифитті микрофлораның сипаттамалары әр түрлі факторлардың әсерінен өзгеріп отыратындықтан, оны зерттеу үнемі өзекті болып қала береді. Өсімдіктердің эпифитті микроорганизмдермен қарым-қатынасының көптеген аспектілері жоғары құндылық пен өзектілікке ие, бірақ толық зерттелмеген. Өсімдіктердің бетінде пайдалы микробтық ценоздардың пайда болуын және микроорганизмдердің өсімдіктермен өзара байланысына әсер ететін жағдайларды анықтайтын факторлар зерттелмеген күйде қалады. Ауыл шаруашылығын дамытуда маңызды рөл атқаратынын атап өткен жөн.

Мақала эпифитті микрофлораның қасиеттерін және оның өсімдіктердің бейімделу қасиеттеріне әсерін зерттеуге арналған. Маусымдық динамикадағы эпифитті микроорганизмдердің сипаттамалары мен таксономиялық құрамы қарастырылады. Теориялық ақпаратты талдау және жалпылау, басып шығару әдісі, жуу әдісі қолданылған.

Өсімдіктердің жер үсті мүшелерінің эпифитті микроорганизмдер өкілдерінің сипаттамалары мен қасиеттері зерттеліп, олардың өсімдік өміріндегі экофизиологиялық рөлі қарастырылды. Микробөсімдіктердің өзара әрекеттесуі саласындағы әртүрлі зерттеулер қарастырылып, талданды. Экологиялық факторлардың эпифиттік микрофлораға әсер ету рөлі анықталды. Lycopersicon esculentum Mill өсімдіктерінің мысалында өсімдіктердің маусымдық динамикасындағы эпифитті микрофлорасының сандық және сапалық құрамының өзгеруі туралы мәліметтер алынды. (қарапайым қызанақ) және Solanum tuberosum L. (түнгі түйнек).

Түйін сөздер: филлосфера, карпосфера, эпифитті микрофлора, фитопатогенді микроорганизмдер.

\author{
А.А. Селихова ${ }^{1 *}$, А.К. Оспанова ${ }^{1}$ Ю.М. Каниболоцкая ${ }^{2}$ \\ ${ }^{1}$ Инновационный Евразийский университет, Республика Казахстан \\ ${ }^{2}$ Сибирский университет потребительской кооперации, Россия
}

\section{Общая характеристика и таксономический состав эпифитной микрофлоры растений}

Изучение растительно-микробных взаимодействий на сегодняшний день остаётся одним из актуальных вопросов биологических и сельскохозяйственных наук. Многими учёными, изучавшими данную проблему, выявлено, что эпифитная микрофлора способствует росту и развитию растений, а также существенно влияет на урожайность, так как находится в теснейшем контакте с растением в течение всего вегетационного периода. Кроме того, характеристики эпифитной микрофлоры настолько изменчивы под влиянием различных факторов, что её изучение остаётся актуальным постоянно. Многие стороны взаимоотношений растений с эпифитными микроорганизмами представляют высокую ценность и актуальность, однако изучены далеко не полностью. Неизученными остаются факторы, определяющие формирование полезных микробных ценозов на поверхности растений и условия, влияющие на взаимосвязь микроорганизмов с растениями. Необходимо отметить, что весомую роль в развитии сельского хозяйства в Республике Казахстан и Павлодарской области выполняют представители овощных культур, в том числе томат и картофель, принадлежащие к семейству паслёновых. Это показывает высокую значимость выбранных для исследования растений. Совокупность вышеизложенных доводов определяет необходимость установления закономерностей воздействия эпифитной микрофлоры на адаптивные свойства растений семейства паслёновые, а также их урожайность. В свою очередь изучение эпифитной микрофлоры может способствовать поиску новых путей повышения урожайности растений а также их устойчивости к различным заболеваниям. 
Цель статьи - изучить свойства эпифитной микрофлоры и её воздействие на адаптивные свойства растений. В статье применены методы анализа и обобщения теоретической информации, метода отпечатка, метода смыва.

В результате исследования авторами изучены характеристики и свойства представителей эпифитных микроорганизмов надземных органов растений и рассмотрена их экофизиологическая роль в жизни растений. Проанализированы различные исследования в области микробно-растительных взаимодействий. Определена роль воздействия экологических факторов на эпифитную микрофлору. Получены данные об изменении количественного и качественного состава эпифитной микрофлоры растений в сезонной динамике на примере растений Lycopersicon esculentum Mill (томат обыкновенный) и Solanum tuberosum L. (паслён клубненосный).

Ключевые слова: филлосфера, карпосфера, эпифитная микрофлора, фитопатогенные микроорганизмы.

Date of receipt of the manuscript to the editor: 2021/05/15 